\title{
Seminoma and sertolioma in a male pseudohermaphrodite dog with unilateral cryptorchidism: short communication
}

\section{Seminoma e sertolioma em um cão pseudo-hermafrodita masculino e criptorquida unilateral: comunicação científica}

\author{
Renata Madureira ${ }^{*}$; Nazilton de Paula Reis Filho²; Angélica Rossotti dos Santos; \\ Ana Lúcia Dias ${ }^{4}$; Selwyn Arlington Headleys; Nilva Maria Freres Mascarenhas'; \\ Juliana Sperotto Brum ${ }^{7}$
}

\begin{abstract}
A male miniature Schnauzer with cryptorchidism and a mass growth in the right inguinal canal was admitted to the clinical center of a veterinary hospital. During surgical resection of the mass, tubular formations were found, connecting the mass to the left testicle. Histopathology revealed that the tubular formations were uterine tubes and the mass was a seminoma associated with a sertolioma of the right testicle. Further analysis also showed atrophy of the left testicle. Cytogenetic evaluation revealed normal chromosomes of male gender, $78, \mathrm{XY}$, which led to the conclusion that this was a male pseudohermaphrodite.
\end{abstract}

Key words: Canine. Cryptorchid. Cytogenetic. Persistent Müllerian duct syndrome. Tumor.

\section{Resumo}

Foi atendido na rotina clínica de um hospital veterinário, um cão, macho, da raça Schnauzer, criptorquida com massa em canal inguinal direito. Durante o procedimento cirúrgico para a retirada da massa, foi encontrada uma formação tubular a qual fazia a ligação entre essa massa e o testículo esquerdo. A análise histopatológica concluiu que a formação tubular tratava-se de tubas uterinas, a massa era o testículo direito com seminoma e sertolioma e o testículo esquerdo apresentava atrofia. A avaliação citogenética revelou cromossomos normais, do sexo masculino, 78, XY concluindo que se tratava de um pseudo-hermafrodita masculino.

Palavras-chave: Canino. Citogenética. Criptorquidismo. Síndrome da persistência dos ductos de Müller. Tumor.

\footnotetext{
1 M.a, Programa de Pós-Graduação em Ciências Veterinárias, Universidade Federal do Paraná, UFPR, Curitiba, PR, Brasil. E-mail: renata.pato.vet@gmail.com

2 Prof., M.e, Faculdades Integradas de Ourinhos, FIO, Ourinhos, SP, Brasil. E-mail: nazilton@hotmail.com

3 Bióloga, Londrina, PR, Brasil. E-mail: angelicarossotti@yahoo.com.br

4 Prof $^{a}$ Dr $^{\mathrm{a}}$, Departamento de Biologia Geral, Universidade Estadual de Londrina, UEL, Londrina, PR, Brasil. E-mail: anadias@ uel.br

5 Prof. Dr., Departamento de Medicina Veterinária Preventiva, UEL, Londrina, PR, Brasil. E-mail: selwyn.headley@uel.br

6 Prof ${ }^{\mathrm{a}} \mathrm{Dr}^{\mathrm{a}}$, Departamento de Clínicas Veterinárias, UEL, Londrina, PR, Brasil. E-mail: mascaren@uel.br

7 Prof $^{\mathrm{a}}, \mathrm{Dr}^{\mathrm{a}}$, Programa de Pós-Graduação em Ciências Veterinárias, UFPR, Curitiba, PR, Brasil. E-mail: julianasbrum@yahoo.com.br

* Author for correspondence
} 
Developmental disorders related to reproduction are well described in dogs. Amongst these is the incomplete descent of the testicles to the scrotum (cryptorchidism), which is the most frequent disorder in this species, followed by testicular hypoplasia and segmental aplasia of the epididymis. Other less common, but fairly important disorders, are sexual developmental anomalies, such as pseudohermaphroditism (FOSTER, 2013).

Pseudohermaphroditism is a rare anomaly with great clinical relevance. It occurs when chromosomal and gonadal sexes are equivalent, but there is a mismatch or ambiguity in phenotype. Individuals may be classified as male or female pseudohermaphrodites according to their gonadal sex (CHRISTENSEN, 2012).

Two types of male pseudohermaphroditism have been described, each one arising from distinct etiologies: impaired androgen-dependent masculinization and persistent Müllerian duct syndrome (PMDS). The first can occur in 3 levels: defects in androgen biosynthesis, in testosterone conversion to dihydrotestosterone (DHT), which is well documented in dogs and cats, and androgen receptor defects. When the process of androgendependent masculinization is disturbed, anomalies will depend on the degree of loss of function of the androgen receptors. If the receptor function is completely lost, animals will visibly present a female phenotype, which comprises a small vagina with cul-de-sac obliteration and no cervix. The uterus will be absent and gonads will present testicular tissue (CHRISTENSEN, 2012).

PMDS can occur in dogs in response to a mutation in genes encoding the Müllerian inhibiting substance (MIS) structure or its receptors (FOSTER, 2013). Affected individuals have male chromosomes $(78, \mathrm{XY})$ and present uterine tubes, a uterine body, cervix and cranial vagina, as well as internal and external male organs (MEYERSWALLEN et al., 1989).

Cryptorchidism is the most common developmental disorder of the reproductive system of dogs. It is defined as an incomplete descent of the testicles to the scrotum. The undescended testicle can be found in the abdomen or pelvis, and the incidence in $\operatorname{dog}$ populations varies from $1 \%$ to $10 \%$. Miniature Poodle, German Spitz, Yorkshire Terrier, Dachshund, Cairn Terrier, Chihuahua, Maltese, Boxer, Pekingese, and Bulldogs are at higher risk of presenting cryptorchidism in the order of the most to least affected. Given that the condition is autosomal gene-related, males and females may carry susceptibility factors, which means that parents and siblings should also be excluded from breeding (ROMAGNOLI; SCHLAFER, 2006).

Cryptorchid dogs are at higher risk of developing testicular neoplasms (FOSTER, 2013). The undescended testicle is 9-13 times more prone to tumor development than the descended testicle (ROMAGNOLI; SCHLAFER, 2006). Testicular neoplasms are common in elderly dogs, less common in horses, and rare in other species (FOSTER, 2013). The most common testicular neoplasms in dogs are Leydig cell tumors, seminomas, and Sertoli cell tumors (LIAO et al., 2009). Metastases are rare, although sertoliomas can occasionally spread to inguinal lymph nodes. More than $50 \%$ of sertoliomas are found in the undescended testicle of cryptorchid dogs. Seminomas are the second most common testicular neoplasms in this species (FOSTER, 2013).

The objective of this study was to report a case of developmental disorder of the reproductive system in a male pseudohermaphrodite dog with 2 testicular neoplasms.

A 9-year-old miniature Schnauzer dog was admitted to the clinical center of a veterinary hospital. The patient had been adopted as a male pup. At the time of admission, the owner reported noticing a right inguinal mass. At physical examination, only the left testicle could be palpated in the scrotum and a firm non-adhered $5.0 \times 4.2 \times 2.5 \mathrm{~cm}$ mass was identified on the right side. Upon ultrasonography, 
the mass presented multiple cavities. The dog was subjected to orchiectomy of the left testicle and resection of the mass, which was at first assumed to be the right testicle. During surgery, no traces of a ductus deferens could be found within the resected tissue; rather, there was a tubular structure of larger diameter attaching one testicle to the other. An exploratory laparotomy was performed for further investigation, during which the tubular structure was found to be adhered not only to the testicles, but also to the bladder. Surgery proceeded with complete resection of the unrecognized structure and all excised material was fixed in $10 \%$ buffered formaldehyde solution for routine histopathological evaluation.

A blood sample was obtained for karyotyping. Mitotic chromosomes were obtained via lymphocyte cultures as described (MOORHEAD et al., 1960), using RPMI medium. Media were supplemented with $0.0125 \%$ colchicine to obtain the greatest number of metaphasic cells. Slides were stained using 5\% Giemsa in phosphate buffer ( $\mathrm{pH} 6.8$ ) for microscopic analysis. For karyotype preparation, chromosomes were classified based on the proposed scheme (LEVAN et al., 1964).

Grossly, the left testicle was enlarged $(2.8 \times 1.5 \times$ $0.5 \mathrm{~cm}$ ) with an epididymis that was proportionally smaller than the normal testicle of a dog of the same age and size (PINHO, 2010). The sectioned surface was brown with a discrete trabecular pattern at its center. The inguinal mass (assumed to be the right testicle and epididymis) was $4.0 \times 3.5 \times 2.5 \mathrm{~cm}$ in size, firm, predominantly light brown with thin multiple whitish trabeculae and red focal areas (Figure 1A). The surface of the tubular structure was smooth and pink and comprised of two distinct parts, that were anatomically similar to uterine horns (each being $7.0 \times 2.0 \times 1.0 \mathrm{~cm}$ ). These structures were connected by a firm area that resembled the uterine body, but with a cul-de-sac end. The tissue was soft on sectioning and the internal wall was diffusely pink and discretely irregular; a small amount of clear fluid was observed within the lumen (Figure 1B).
Histopathology of the left testicle revealed reduced seminal tubules, characterized by the loss of spermatocyte layers and absence of spermatozoa, along with intense proliferation of connective tissue. These findings were compatible with diffuse and intense testicular atrophy.

Microscopically, the right testicle presented neoplastic proliferation of two distinct cell populations and a fibrous capsule. The first population, germinative in origin, formed a wellenclosed cover of round cells with moderately eosinophilic cytoplasm and round vacuolar nuclei with a mean of two mitoses per high-power field (400x). The second population originated from supporting cells (Sertoli cells) and was characterized by well-defined lobules surrounded by a thin layer of collagenous tissue. Cells in this population presented a distinct cytoplasm with irregular edges, round to elongated nuclei, and slight anisokaryosis with up to four mitoses per high-power field $(400 \mathrm{x})$. These neoplasms were thus classified as seminoma (Figure 2A) and sertolioma (Figure 2B), respectively. Histologically, the tubular structure was interpreted as representing uterine tubes (Figure 2C) characterized by an external layer of connective tissue with few vessels and an internal layer compatible with endometrium. In the endometrial tissue, a stratified pavement epithelium with numerous simple tubular glands (uterine glands) was identified, including many mononuclear and polymorphonuclear cells. No ovarian tissue was found in the analyses.

Cytogenetic investigation revealed normal chromosomes indicating male gender, 78, XY (Figure 1C). Based on the cytogenic analysis and the results of other similar studies (MATSUU et al., 2009; BIGLIARDI et al., 2011), it was possible to confirm a normal male karyotype in this $\operatorname{dog}(2 n=$ $78, \mathrm{XY})$. Considering that the gonads were those of a male, in association with the $78 \mathrm{XY}$ karyotype, and the presence of uterine tubes indicates that this was this a case of male pseudohermaphroditism. 
Figure 1. Macroscopy and karyotyping of a male pseudohermaphrodite dog. A) Observe the left testicle with a brown sectioned surface and discrete trabecular pattern at the center. The right testicle had firm consistency, light brown sectioned surface with thin multiple whitish trabeculae and foci of red areas. B) The tubular structure observed at the site of the ductus deferens, connecting one testicle to other. C) Metaphasic chromosomes can be seen at the top. The arrow indicates the $\mathrm{X}$ chromosome and the arrow head indicates the $\mathrm{Y}$ chromosome. Karyotype $76 \mathrm{~A}+\mathrm{XY}$ is at the bottom.
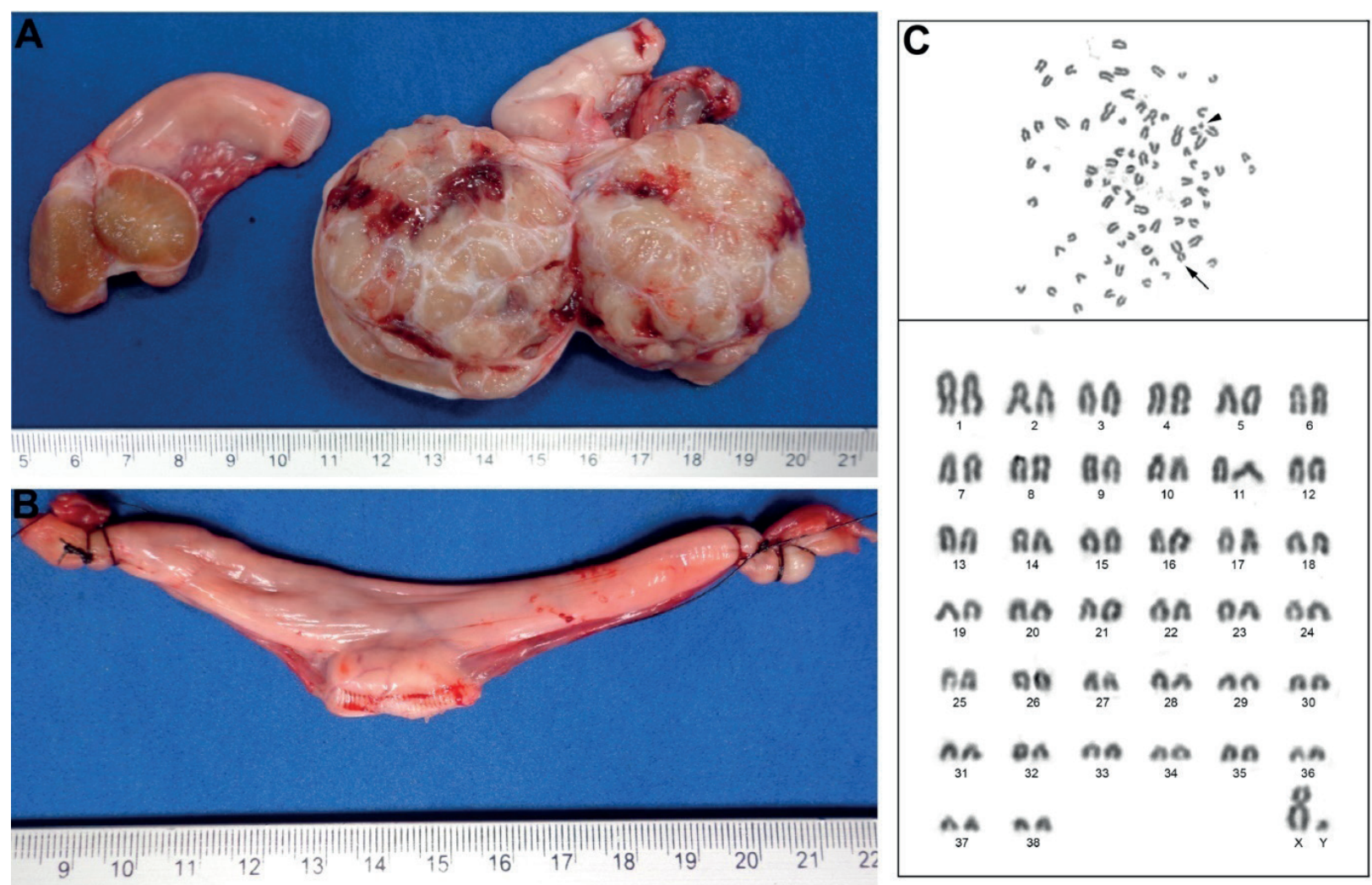

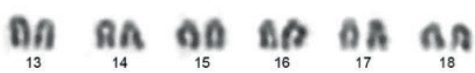

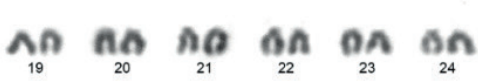

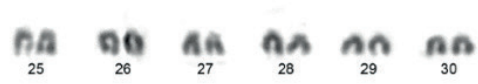

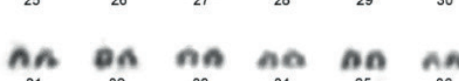

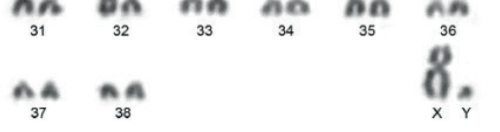

Figure 2. Histopathological findings observed in a male pseudohermaphrodite dog. A) Seminoma: there is a layer of round cells that demonstrated moderate pleomorphism and anisokaryosis, round vacuolar nuclei and evident nucleoli. Hematoxylin and eosin (H\&E) staining. Bar $=10 \mu \mathrm{m}$. B) Sertolioma: well-defined lobules of cellular population separated by a thin layer of collagenous tissue and cytoplasm with irregular edges; there is discrete to moderate anisokaryosis and round to elongated nuclei. H\&E. Bar $=10 \mu \mathrm{m}$. C) Tubular structure (uterine tubes): endometrium with stratified pavement endothelium and numerous tubular glands (uterine glands) (arrows). H\&E. Bar $=10 \mu \mathrm{m}$.
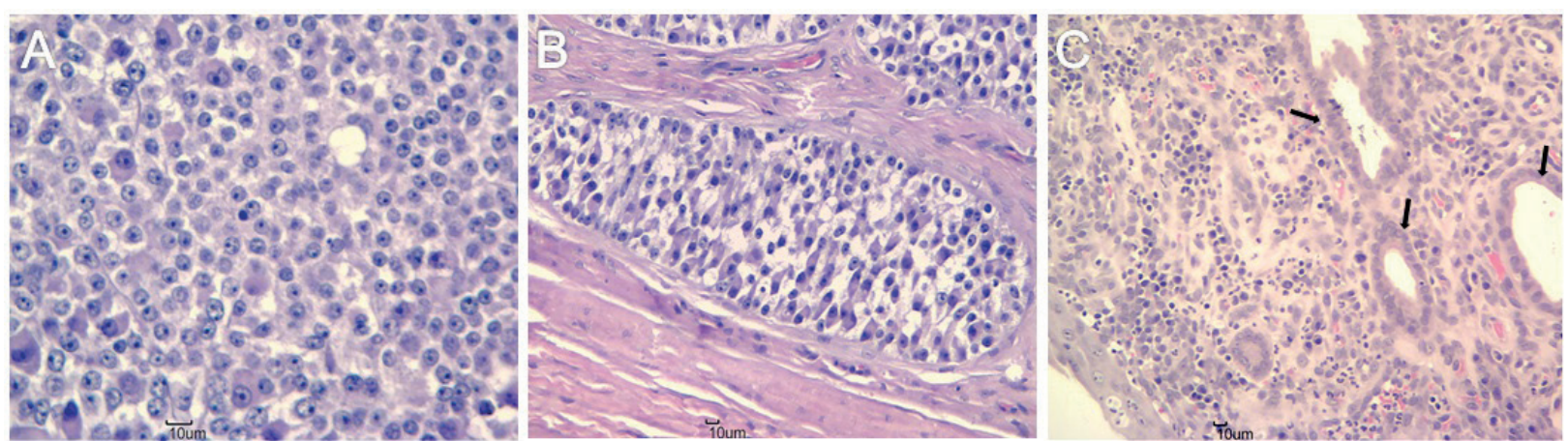
Humans with PMDS present a normal male karyotype and both testes (JOSSO et al., 2005). Dogs, however, in addition to normal internal genitalia, present persistent Müllerian ducts with both tubes, the uterus, and cervical and cranial vagina (MEYERS-WALLEN, 2012). Our findings are corroborated by the fact that this animal presented only uterine tubes, and no other female characteristics, along with a normal karyotype.

The frequency of pseudohermaphroditism in animals with PMDS has not yet been established. There are reports of familial PMDS in miniature Schnauzer dogs in the USA (MEYERS-WALLEN et al., 1989) and in Japan (MATSUU et al., 2009). Meyers-Wallen et al. (1989) suggested that these dogs can be used to improve our understanding of the syndrome in humans, since PMDS in miniature Schnauzer dogs is inherited as an autosomal recessive trait that is limited to homozygous males. Similar reports have been described in other breeds, such as the Basset Hound, American Cocker Spaniel, Yorkshire Terrier, and in cats (MEYERS-WALLEN, 2012; ALAM et al., 2007; DIANOVSKÝ et al., 2013).

In humans, the MIS is known to be produced by Sertoli cells in fetal testicles and is responsible for the regression of Müllerian duct in male fetuses (JOSSO et al., 2005). Affected dogs secrete bioactive MIS during a critical time of embryonic development (MEYERS-WALLEN et al., 2012), which suggests that its disturbance in individuals affected by the syndrome is a lack of response to MIS stimulation, possibly due to a defect in the genes encoding these receptors (FOSTER, 2013). Similar to humans, research to date has focused finding mutations in SRY and SOX9 (DIANOVSKÝ et al., 2013), which would be related to MIS. It is believed that $50 \%$ of dogs with PMDS are cryptorchid (MEYERSWALLEN, 2012). The latter anomaly was observed in the present study and we believe it is related to the malformation. The connection between the testicles and the uterine horn physically interferes with testicle descent (MEYERS-WALLEN, 2012).
Unilateral cryptorchidism is more frequent than bilateral cryptorchidism in dogs. Most testicles with incomplete descent are found on the right side (FOSTER, 2013), which is similar to our observation in this case. Cryptorchidism has also been reported in human patients with PMDS as a common finding, together with the Fallopian tubes, uterus, and anterior vagina. These patients are phenotypically normal (JOSSO et al., 2005). The canine model offers a clinical insight into patients with PMDS. Most of the diagnosis is performed at the time of surgical repair of the undescended testicle in children, or when adults are found to be infertile (MEYERS-WALLEN, 2012).

The right undescended testicle in this case presented two distinct neoplasms, which may have been predisposed by the pseudohermaphroditism herein described. Liao et al. (2009) reported that seminoma is amongst the most common testicular neoplasms in cryptorchid dogs (19/52), and is often associated with sertolioma (16/52). Furthermore, these authors have observed that $54.2 \%$ (52/96) of testicular tumors are cryptorchid. Complications caused by undescended testicles include a higher incidence of sertoliomas and seminomas. Statistically there is also a higher incidence of testicular tumors in animals less than 10 years-old when cryptorchidism is present (LIAO et al., 2009), which is corroborated by the findings in this dog. The development of tumors in abdominal or inguinal testicles might be related to the higher temperatures in those areas (ROMAGNOLI; SCHLAFER, 2006).

Cryptorchid pseudohermaphrodite Schnauzer dogs with sertoliomas have been reported by a few authors (NORRADIN; BAUM, 1970; MATSUU et al., 2009). The presence of two types of neoplasm was reported in a pseudohermaphrodite dog, which presented a Leydig cell tumor on the right testicle and a Sertoli cell tumor on the left testicle (BIGLIARDI et al., 2011). Additional reports of pseudohermaphrodites with sertolioma and seminoma in the same testicle were not located when major databases were accessed. 
In addition to the cryptorchidism and neoplasms, the dog herein described also presented atrophy of the left testicle. This characteristic is associated with aging; which might be related to the cryptorchidism or it can occur unilaterally, as a result of an estrogensecreting tumor on the contralateral testicle (FOSTER, 2013). In this case, testicular atrophy was associated with the presence of the contralateral tumors. Norradin and Baum (1970) have reported a case of a pseudohermaphrodite dog, a miniature Schnauzer, which presented a sertolioma and contralateral atrophy, as well as mucometra. Macroand microscopic analyses showed no changes in the tubular formation in the patient in the present report.

In conclusion, pseudohermaphroditism is a rare condition in dogs, especially when associated with sertolioma and seminoma. Therefore, the present study contributes to the understanding of male pseudohermaphroditism concomitant with neoplasms in dogs in which persistent Müllerian duct syndrome is the probable cause.

\section{References}

ALAM, M. R.; CHO, Y. G.; CHO, S. J.; LEE, J. I.; LEE, H. B.; TAE, H. J.; KIM, I. S.; KIM, N. S. Male pseudohermaphroditism in dogs: 3 case reports. Veterinárni Medicína, Praha, v. 52, n. 2, p. 74-78, 2007.

BIGLIARDI, E.; PARMA, P.; PERESSOTTI, P.; LORENZI, L. D.; WOHLSEIN, P.; PASSERI, B.; JOTTINI, S.; CANTONI, A. M. Clinical, genetic, and pathological features of male pseudohermaphroditism in dog. Reproductive Biology and Endocrinology, London, v. 12, n. 9, p. 1-7, 2011.

CHRISTENSEN, B. W. Disorders of sexual development in dogs and cats. Veterinary Clinics: Small Animal Practice, Ames, v. 42, n. 3, p. 515-526, 2012.

DIANOVSKÝ, J.; HOLEČKOVÁ, B.; HAJURKA, J.; ŠIVIKOVÁ, K.; CIGÁNKOVÁ, V. Disorder of sexual development in a Yorkshire terrier (78, XY; SRYpositive). Journal of Applied Genetics, Poznań, v. 54, n. 2, p. 193-199, 2013.

FOSTER, R. A. Sistema reprodutor do macho. In: ZACHARI, J. F.; MCGAVIN, M. D. Bases da patologia veterinária. 5. ed. Rio de Janeiro: Mosby Elsevier, 2013. chap.19, p. 1134-1147.
JOSSO, N.; BELVILlE, C.; CLEMENTE, N. DI; PICARD, J. Y. AMH and AMH receptor defects in persistent Müllerian duct syndrome. Human Reproduction Update, Oxford, v. 11, n. 4, p. 351-356, 2005.

LEVAN, A.; FREDGA, K.; SANDBERG, A. A. Nomenclature for centromeric position at chromosomes. Hereditas, Malden, v. 52, n. 2, p. 201-220, 1964.

LIAO, A. T.; CHU, P. Y.; YEH, L. S.; LIN, C. T.; LIU, C. H. A 12-year retrospective study of canine testicular tumors. Theriogenology, Los Altos, v. 71, n. 7, p. 919$923,2009$.

MATSUU, A.; HASHIZUME, T.; KANDA, T.; NAGANO, M.; SUGIYAMA, A.; OKAMOTO, Y.; HIKASA, Y. A case of persistent müllerian duct syndrome with sertoli cell tumor and hydrometra in a dog. Jounal Veterinary Medicine Science, Tokyo, v. 71, n. 3, p. 379381, 2009.

MEYERS-WALLEN, V. N. Gonadal and sex differentiation abnormalities of $\operatorname{dogs}$ and cats. Sexual Development, Basel, v. 6, n. 1-3, p. 46-60, 2012.

MEYERS-WALLEN, V. N.; DONAHOE, P. K.; UENO, S.; MANGANARO, T. F.; PATTERSON, D. F. Müllerian inhibiting substance is present in testes of dogs with persistent müllerian duct syndrome. Biology of Reproduction, Madson, v. 41, n. 5, p. 881-888, 1989.

MOORHEAD, P. S.; NOWELL, P. C.; MELLMAN, W. J.; BATTIPS, D. M.; HUNGERFORD, D. A. Chromosome preparations of leukocytes cultured from human peripheral blood. Experimental Cell Research, San Diego, v. 20, n. 3, p. 613-616, 1960.

NORRADIN, R. W.; BAUM, A. C. A male pseudohermaphrodite dog with a Sertoli's cell tumor, mucometra, and vaginal glands. Journal of American Veterinary Medical Association, New York, v. 156, n. 2, p. 204-207, 1970.

PINHO, T. C. S. D. Mensuração testicular de cães (Canis familiaris) hígidos por meio de exame ultrassonográfico. 2010. Dissertação (Mestrado em Clínica e Reprodução Animal) - Pós-Graduação em Medicina Veterinária da Universidade Federal Fluminense, Niterói.

ROMAGNOLI, S.; SCHLAFER, D. H. Disorders of sexual differentiation in puppies and kittens: a diagnostic and clinical approach. Veterinary Clinics Small Animal Practice, Ames, v. 36, n. 3, p. 573-606, 2006. 